\title{
Physico-chemical properties and heavy metal contents of a tropical estuarine ecosystem, Nigeria
}

\section{Paul Chinedu Echi*, Daberechi Ndudim Okpechi, Urum Janet Azu and Izuchukwu Samson Arukwe}

Department of Zoology and Environmental Biology, Michael Okpara University of Agriculture, Umudike, Nigeria.*mail: paul_echi@yahoo.com.

\begin{abstract}
Ibaka Estuarine in Mbo, Nigeria, has little or no information on its basic properties, therefore its water samples were studied from March to June 2018 in three different stations and compared with International Standards to evaluate its physic-chemical properties as well as heavy metal contents. The physic-chemical properties studied include $\mathrm{pH}$, salinity (g/L), EC $(\mu \mathrm{s} / \mathrm{cm})$, turbidity (NTU), total suspended solids $(\mathrm{mg} / \mathrm{L})$, total dissolved solids $(\mathrm{mg} / \mathrm{L})$, dissolved oxygen $(\mathrm{mg} / \mathrm{L}), \mathrm{BOD}_{5}(\mathrm{mg} / \mathrm{L})$, and chemical oxygen demand $(\mathrm{mg} / \mathrm{L})$. In addition, some metal concentrations of manganese, iron, copper, lead, zinc, cadmium, chloride and magnesium were determined by atomic absorption spectroscopy (AAS). The range of metal concentrations manganese (0.08-0.12 mg/L), copper (0.05-0.09 mg/L), lead (0.01-0.03 mg/L), iron (1.86-4.66 mg/L), zinc (0.68-1.16 mg/L), cadmium (0.04-0.08 mg/L), chloride (675.0-791.25 mg/L), magnesium (10.66-14.30 mg/L). The study infers that anthropogenic pressure plays damaging role to its properties in addition to general health implication of high values for $\mathrm{Fe}, \mathrm{Zn}$, $\mathrm{Cd}, \mathrm{Cl}$ and $\mathrm{Mg}$ which exceeded international standard.
\end{abstract}

Keywords: Ibaka Estuarine; Aquatic ecosystem; Heavy metals; Physic-chemical parameters.

\section{Introduction}

The vast aquatic ecosystems in the Niger Delta region with a lot of resources supply food and domestic water use for the inhabitants.
Received

November 24, 2018

Accepted

December 21, 2018

Released

December 31, 2018

Full Text Article

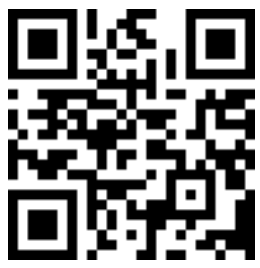

\footnotetext{
ORCID

D) 0000-0001-5868-1142

Paul Chinedu Echi

(D) 0000-0003-0715-2405

Daberechi Ndudim Okpechi

(ㄷ) 0000-0003-1386-648X Janet Azu Urum

(ㄷ) 0000-0003-3519-5277

Izuchukwu Samson

Arukwe
}

Although sea-food gives nutrients for healthy living, developing children, during ill health and expectant mothers, its nutritional values could be affected as the contamination of the environment by industries and other human activities in 
which they live continues to be a public health concerns (Nsikak et al., 2007). These important food sources constitute a major part of the diet in the Niger Delta region of Nigeria, where they are traditionally cooked without removing the shells before consumption and these organisms could be contaminated with heavy metals which may be detrimental to the health of children, pregnant women and even the general public. The concern over large consumption of sea foods by large individuals in Niger Delta borders mainly on heavy metals that are common source of contamination from various human industrial activities. This is particular important due to their toxicity to life forms and long lasting residual effects in nature that readily involve trophic relationship (Otitoju and Otitoju, 2013). Metals may be broadly classified into three environmental significant groups. This includes non toxic but accessible, toxic but not accessible and toxic and accessible. The latter group has both concerns on environmental pollution and public health. They are trace elements with densities $5 \mathrm{~g} / \mathrm{cm}^{3}$ (Dara, 1993).

The introduction of noxious substances in level that can affect humans cause unwanted environmental changes. This could severely change the composition of biodiversity with aquatic ecosystem being predictively faced with greater consequences (Sala et al., 2000). This is attributable to uncontrolled agricultural practices and not enough attention to their environmental consequences (Ghorade et al., 2014). The afore-mentioned activities introduce heavy metals into the environment. Although these elements are essential to living organisms (Lane and Morel, 2000), they portend danger at comparatively high concentration (Domingo, 1994; Goorzadi et al., 2009). Pollution caused by high level heavy metals of soil and water is one of the main considerations nowadays (Namaghi et al., 2011). Metallic element possessing comparatively high density; atomic density greater than $4 \mathrm{~g} / \mathrm{cm}^{3}$ and they are known to be toxic to organisms in high concentration in the environment (Awni, 2010; Abdel Gawad, 2018a, b). They accumulate in tissues of living organisms interact with cellular elements as to replace essential minerals, affect metabolic processes, which may result to systemic poisoning (Nord, 2016; Jaish-ankar et al., 2014). The residual effects of heavy metals gradually collect unchangeably in the tissues of organisms at various trophic levels as time goes on, then it will result in heavy metal related diseases. This is because fish which is at the top of aquatic food chain and readily consumed by man will cause bioaccumulation of these elements in man and their attendant toxicity (Mallampati et al., 2007; Dirican et al., 2013). Therefore, effects are hinged on their capacity to remain in the environment for a long time, cause debilitating diseases due to its ability to bioaccumulate in tissues of organisms in higher trophic levels as well as capable of causing tetratogenic effects (Abdulaziz and Mohammed, 1997; Mallampati et al., 2007; Akpo and Muchie, 2010).

Appreciable numbers of studies have been recorded from various aquatic ecosystems in Niger Delta region of Nigeria with reports cautioning on the heavy metal contents of the sediments, water, flora and fauna that inhabit these aquatic ecosystems such as (Nsikak et al., 2007; Otitoju and Otitoju, 2013; Iwuoha and Onojake, 2016).

\section{Materials and method}

Ibaka Estuarine Ecosystem $4^{\circ} 39^{\prime} 13.53^{\prime \prime} \mathrm{N}$ and $8^{\circ} 18^{\prime} 50.778^{\prime \prime} \mathrm{E}$ has little or no information although it is located in the Niger Delta where many reports have emanated. Sampling was carried out monthly from March to June, 2018, and three stations were designated for this purpose.

The entire sampling stations were brackish water and selections of sampling stations were governed by 
accessibility and human activities. Two stations (Station One $4^{\circ} .39^{\prime} 13.53^{\prime \prime} \mathrm{N}$ and $8^{\circ}$ 18' 52. 93" E, and Station Two $4^{\circ} 39^{\prime} 25.77^{\prime \prime} \quad \mathrm{N}$ and $\left.8^{\circ} 18^{\prime} 53.54^{\prime \prime} \quad \mathrm{E}\right)$ witnessed the most human activities such as packing of canoe, speed boat, ships, bathing, washing, swimming, and fetching of water for household but Station Three $\left(4^{\circ} 39^{\prime} 41.64^{\prime \prime} \mathrm{N}\right.$ and $8^{\circ} 19^{\prime} 3.68^{\prime \prime}$ E) only witnessed intensive fishing activities throughout the study period. It is located some meters to the community market. This proximity allows easy discard of refuse both organic and inorganic materials into this water body. Many tributaries of it are established in many other communities. In Ibaka estuarine community, the water serves for drinking, washing, cooking and recreational purposes. The land is fine sand that can worsen erosion.

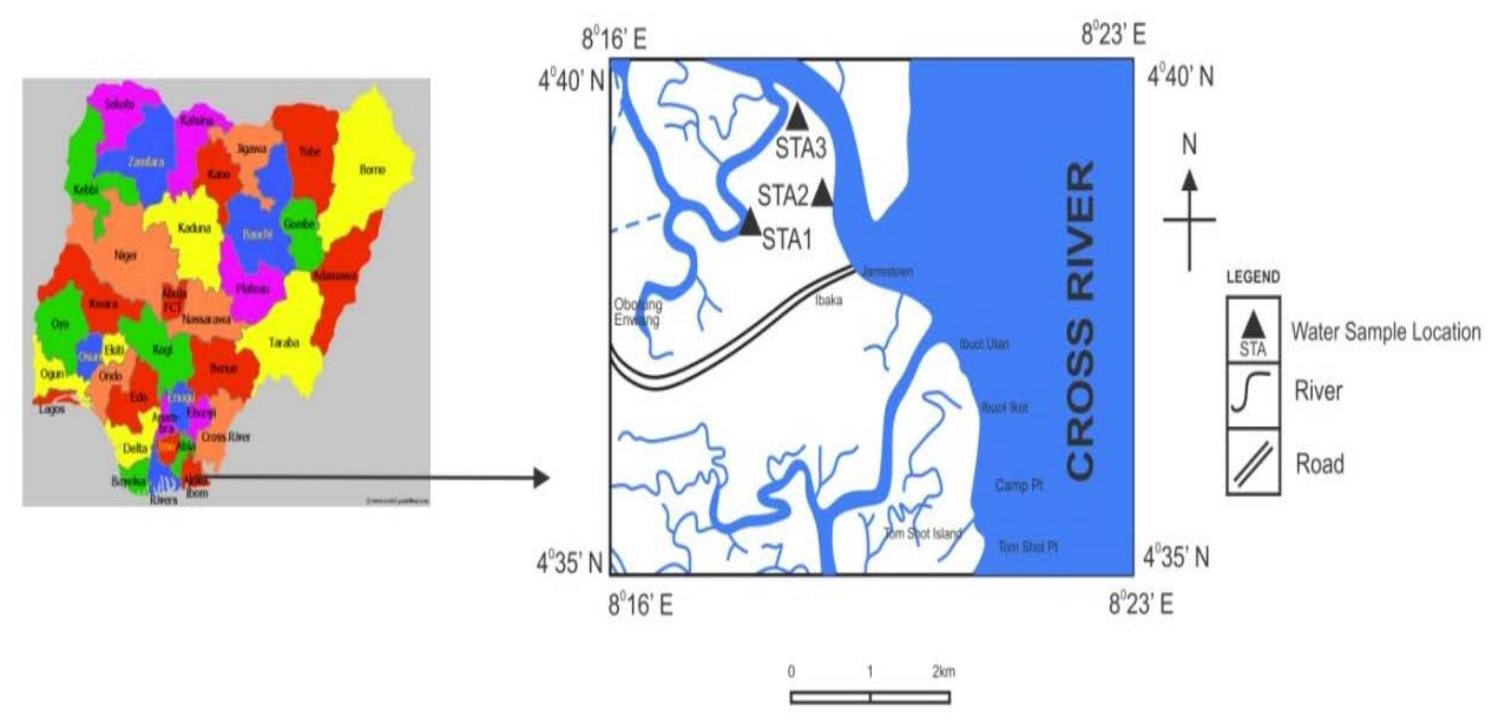

Figure 1. Map of the study area.

\section{Water analysis}

The water samples were collected from different stations once each month. The $\mathrm{pH}$, temperature, electric conductivity and other parameters were determined in situ according to Abowei (2010). The samples for BOD were collected in BOD bottles, to which 1 or $2 \mathrm{~mL}$ of potassium iodide are added and sealed. This is mixed and the precipitate allowed to settle down. At this stage 1 or $2 \mathrm{~mL}$ of concentrate sulphuric acid is added, and mixed well until all the precipitate dissolves. $203 \mathrm{~mL}$ of the sample is measured into the conical flask and titrated against $0.025 \mathrm{~N}$ sodium thiophosphate using starch as an indicator. The end point is the change in color from blue to colorless (APHA, 1995).

The samples for the heavy metals component analysis were collected with a $1 \mathrm{~L}$ water sampler, transferred into a clean $250 \mathrm{~mL}$ plastic bottle and acidified with nitric acid $\left(\mathrm{HNO}_{3}\right)$ according to Sharma and Tyagi (2013). The mixture was gently heated on a hot plate, heated for another $10 \mathrm{~min}$ and allowed to cool. About $5 \mathrm{~mL}$ of $\mathrm{HNO}_{3}$ was used to rinse the sides of the beaker. The solution was quantitatively transferred into a $100 \mathrm{~mL}$ volumetric flask and made up to the mark with distilled water (Zhang, 2007). 
For the heavy metal analysis, the UNICAM Solar 969 atomic absorption spectrometry (AAS) which uses acetylene-air flame was used for the determination of heavy metals. The source of radiation is a hallow lamp, which contained a cathode constructed from the same metals that are being analyzed. This emitted the wave length characteristic of metal; and a different lamp was used for each metal. The light from the lamp was directed through the flame and onto a monochromator, which selected the preferred analytical wavelength. The light monochromator was detected by a photomultiplier tube and converted to an electrical signal. The sample was aspirated in the flame where the solution was evaporated and the metal-containing compounds volatized and dissociated into ground state atoms.
The ground state atoms absorbed the radiation from the hallow lamp and excited to higher energy level. Some atoms were also thermally excited but their fraction was so small that it caused no error in the analysis (LENNTECH, 2012).

\section{Result}

The $\mathrm{pH}$, electrical conductivity (EC), salinity, turbidity, total suspended solid (TSS), total dissolved solid (TDS), dissolved oxygen (DO), bio-chemical oxygen demand (B0D), chemical oxygen demand (COD) and some heavy metal content of Ibaka water body in Mbo L.G.A, of Akwa Ibom State, are shown in Table 1.

Table 1. Physico-chemical parameters and heavy metals of the water.

\begin{tabular}{lcccc}
\hline Parameter & Station 1 & Station 2 & Station 3 & $\begin{array}{c}\text { WHO } \\
\mathbf{( 2 0 1 7 )}\end{array}$ \\
\hline $\mathrm{pH}$ & $6.03 \pm 0.17$ & $6.18 \pm 0.33$ & $6.4 \pm 0.36$ & $6.5-8.5$ \\
$\mathrm{EC}(\mu \mathrm{s} / \mathrm{cm})$ & $4682.19 \pm 12.02$ & $5358.65 \pm 13.68$ & $4819.74 \pm 12.93$ & 1000 \\
Salinity (g/L & $5.44 \pm 2.12$ & $6.19 \pm 2.42$ & $5.85 \pm 2.18$ & - \\
Turbidity (NTU) & $0.48 \pm 0.17$ & $0.73 \pm 0.17$ & $0.63 \pm 0.09$ & 15 \\
Total suspended $\quad$ solids & $1.33 \pm 0.51$ & $2.12 \pm 0.70$ & $1.63 \pm 0.63$ & - \\
(mg/L) & & & & \\
Total dissolved solids (mg/L) & $6.19 \pm 4.76$ & $6.81 \pm 2685.88$ & $6.38 \pm 2379.82$ & 500 \\
Dissolved oxygen (mg/L) & $4.9 \pm 1.24$ & $5.65 \pm 0.78$ & $4.93 \pm 0.79$ & 5 \\
BOD $D_{5}(m g / L)$ & $1.4 \pm 0.32$ & $1.98 \pm 0.17$ & $2.58 \pm 0.89$ & 5 \\
Chemical oxygen demand & $3.05 \pm 0.99$ & $3.65 \pm 1.14$ & $8.4 \pm 3.37$ & 10 \\
$\mathrm{Mn}$ & $0.08 \pm 0.33$ & $0.12 \pm 0.06$ & $0.09 \pm 0.04$ & 0.2 \\
$\mathrm{Cl}$ & $675 \pm 175.39$ & $791.25 \pm 173.79$ & $714.75 \pm 156.45$ & 250 \\
$\mathrm{~Pb}$ & $0.01 \pm 0.001$ & $0.01 \pm 0.001$ & $0.03 \pm 0.05$ & 2.0 \\
$\mathrm{Fe}$ & $1.86 \pm 0.64$ & $4.66 \pm 1.94$ & $3.66 \pm 1.59$ & 0.003 \\
$\mathrm{Zn}$ & $0.68 \pm 0.22$ & $1.16 \pm 0.42$ & $0.84 \pm 0.21$ & 0.05 \\
$\mathrm{Cd}$ & $0.04 \pm 0.02$ & $0.08 \pm 0.02$ & $0.07 \pm 0.01$ & 0.01 \\
$\mathrm{Cu}$ & $0.05 \pm 0.02$ & $0.09 \pm 0.02$ & $0.06 \pm 0.02$ & 3.0 \\
$\mathrm{Mg}$ & $10.66 \pm 4.600$ & $14.30 \pm 4.92$ & $12.61 \pm 4.58$ & 0.20 \\
\hline
\end{tabular}

The $\mathrm{pH}$ of the water samples from Ibaka water body at Mbo varied from 6.03 to 6.18 (slightly acidic/ moderately acidic) the lowest $\mathrm{pH}$ was recorded at station 1 in March, 2018 where anthropogenic activities take place, while the highest $\mathrm{pH}$ was recorded at station 3 in April, 2018. They are indicative of human activities pressure on the water body (Figure 2). 
Electrical conductivity values ranges from 4,682.19 $\mu$ s/cm to 5,358.68 $\mu \mathrm{s} / \mathrm{cm}$ (Table 1). The lowest conductivity value was record in station 1 in March, 2018 while the highest was recorded in station 2 in March 2018 (Table 1) the temporal and spatial variations of electrical conductivity in Ibaka water body are shown in Figure 3.

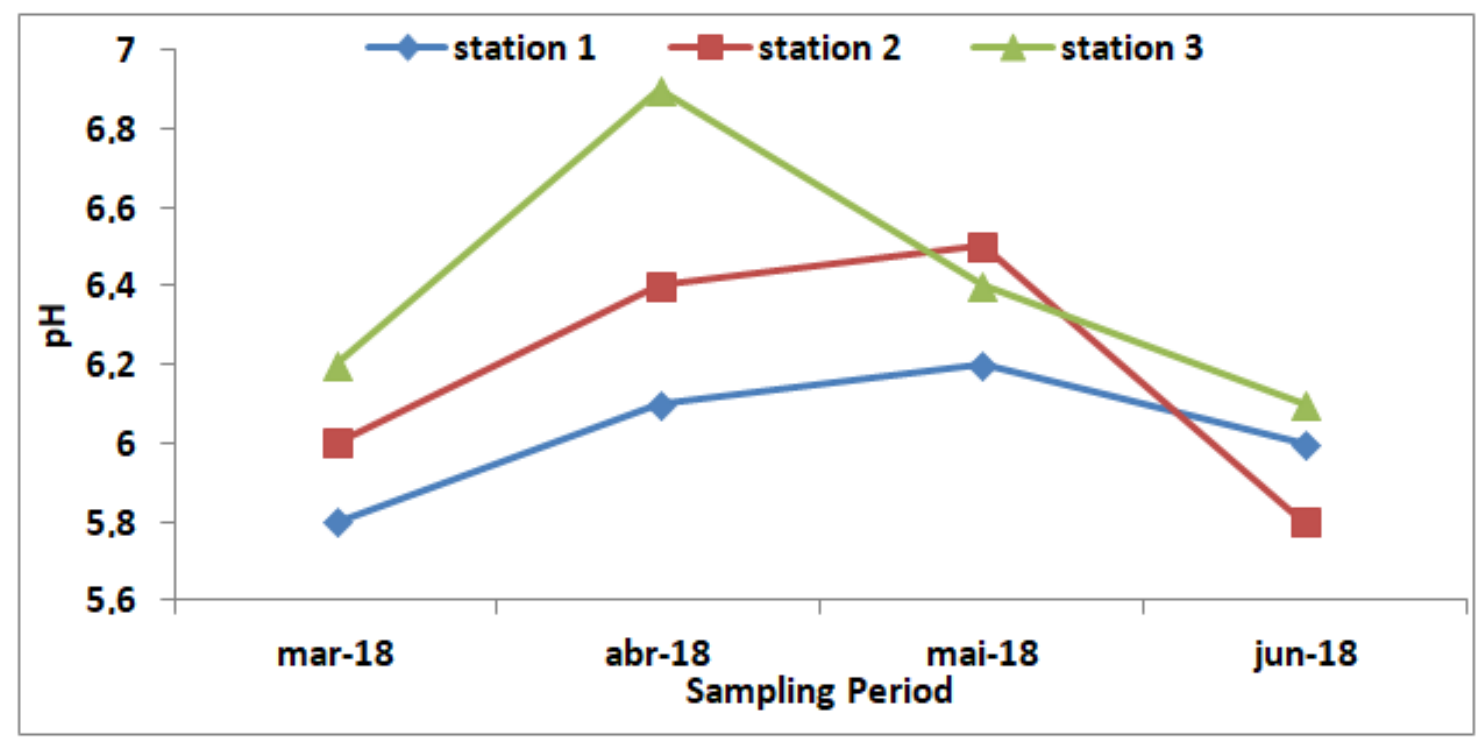

Figure 2. Temporal and spatial variations of $\mathrm{pH}$ (NTU) recorded in the study stations.

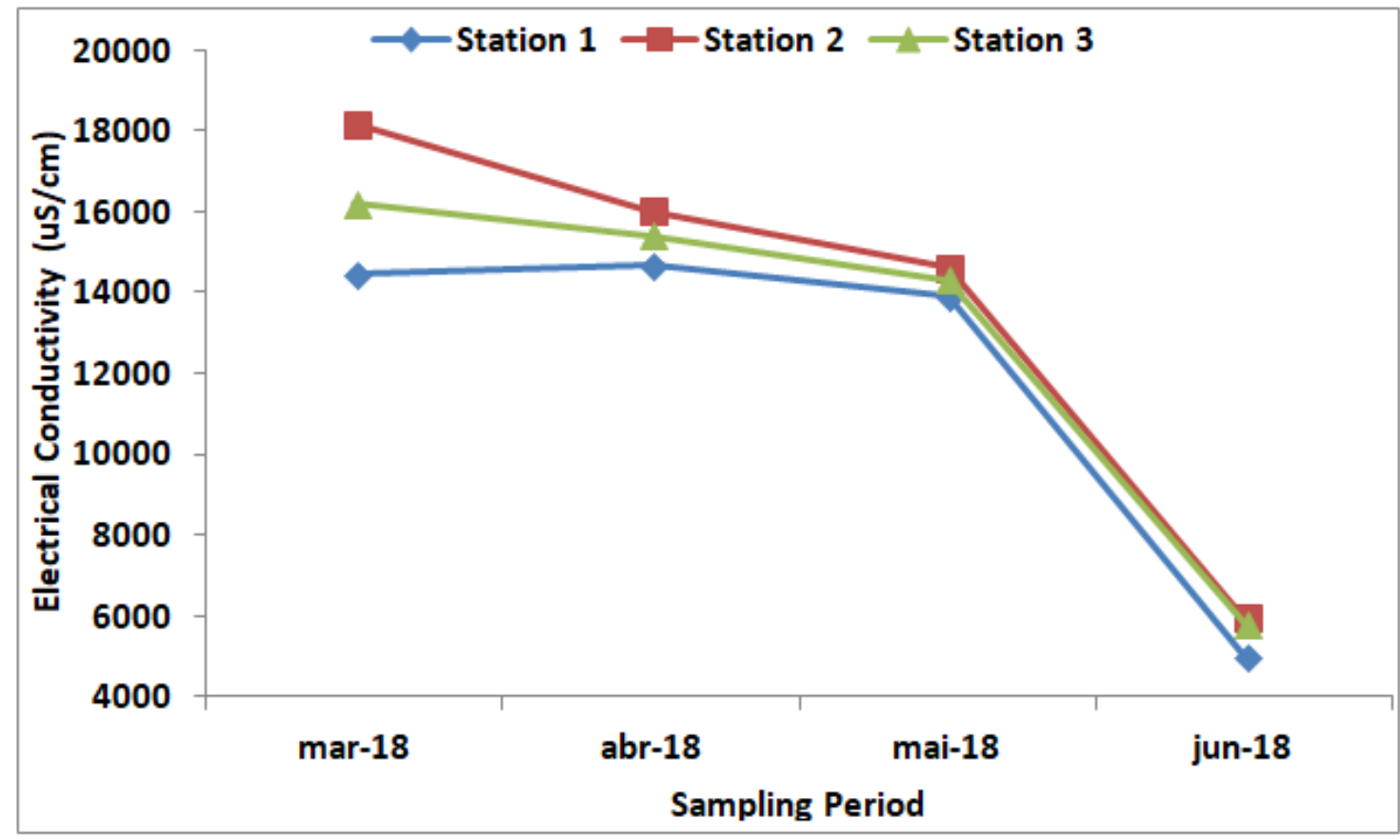

Figure 3. Temporal and spatial variations of electrical conductivity recorded in the study stations. 
Salinity of Ibaka water body was recorded, the mean value was high at station 2 (6.19). The highest station had (2.42). The least salinity recorded was at station 1 (Table 1 ) the salinity of this Ibaka water body showed that it is a brackish water body. The temporal and spatial variations of salinity in Ibaka water body is shown in Figure 4.
The turbidity of Ibaka water body shows that station 2 had the highest mean value recorded. Station 1 had the lowest record of turbidity (Table 1 ). The values recorded are within the acceptable maximum permitted range. The temporal and spatial variations of turbidity are shown in Figure 5.

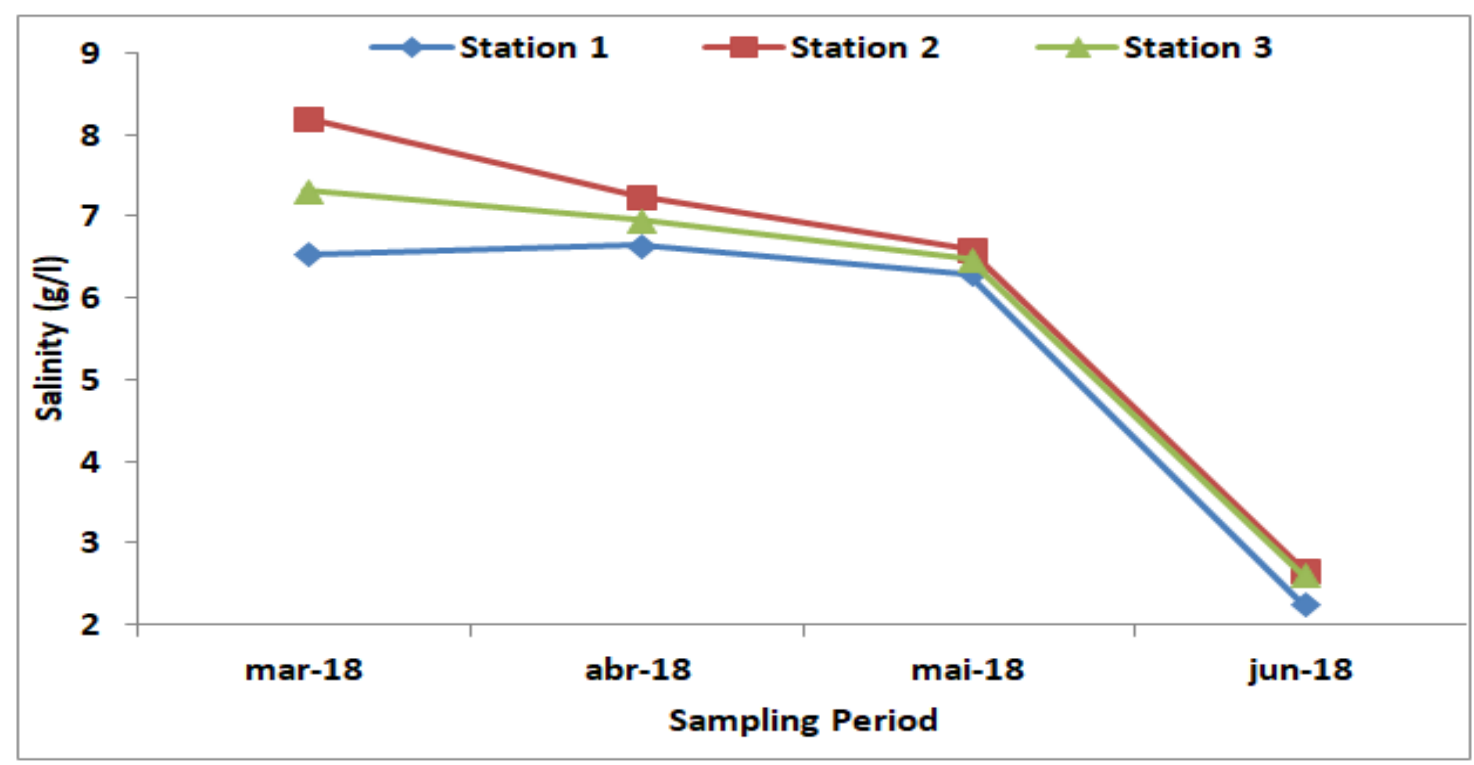

Figure 4. Temporal and spatial variations of salinity recorded in the study stations.

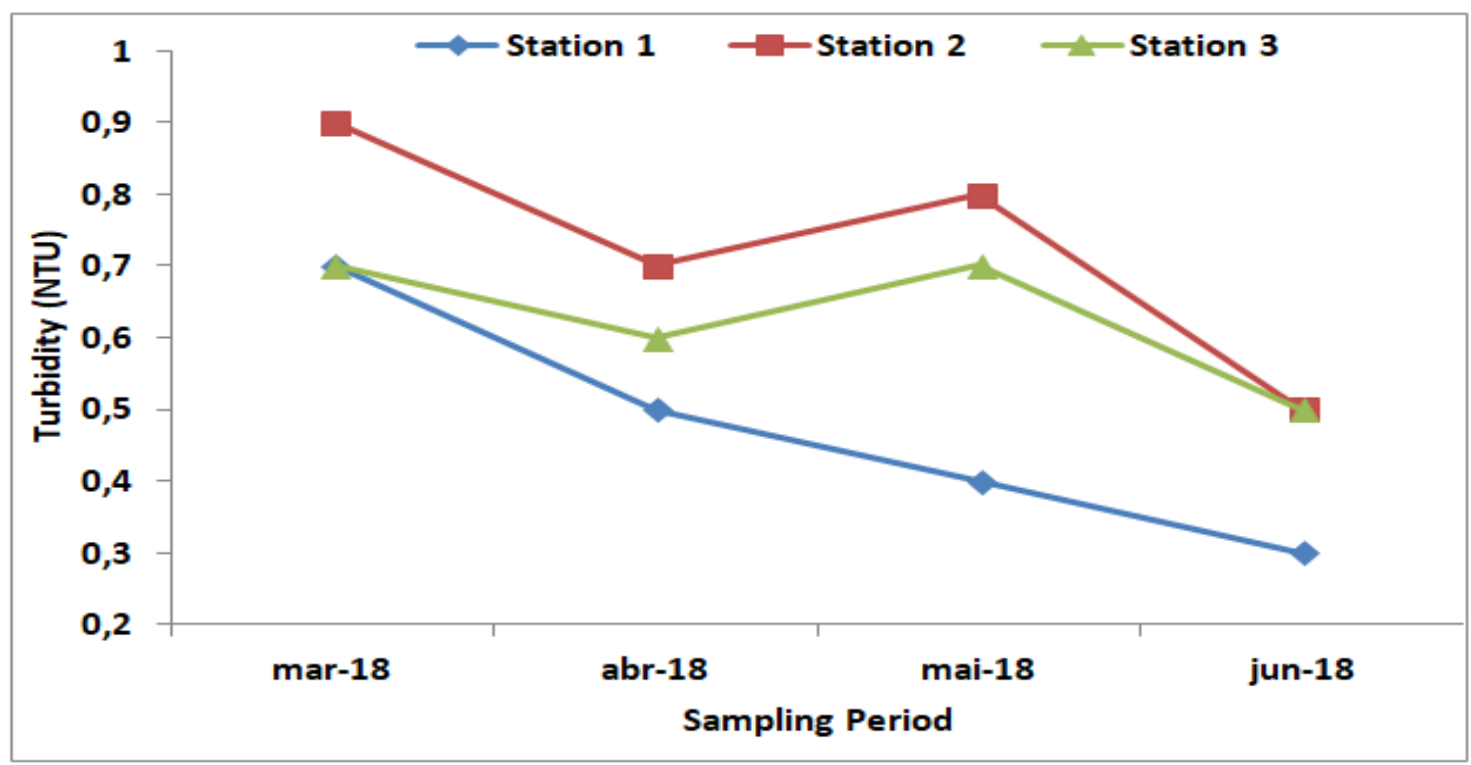

Figure 5. temporal and spatial variations of turbidity (NTU) recorded in the study stations. 
The total suspended solids were recorded at station 2 to be the highest. Station 1 had the lowest (Table 1). The temporal and spatial variations of TSS is shown in Figure 6.

The total dissolved solids were recorded to be low at station 1 and station 2 had the highest record (Table
1) the highest value which is at station 2 is $9,121 \mathrm{mg} / \mathrm{L}$ in March, 2018. The lowest value is at station 1 in June, 2018. The values recorded show that it is not accepted within the acceptable maximum permitted range. The temporal and spatial variation is shown in Figure 7.

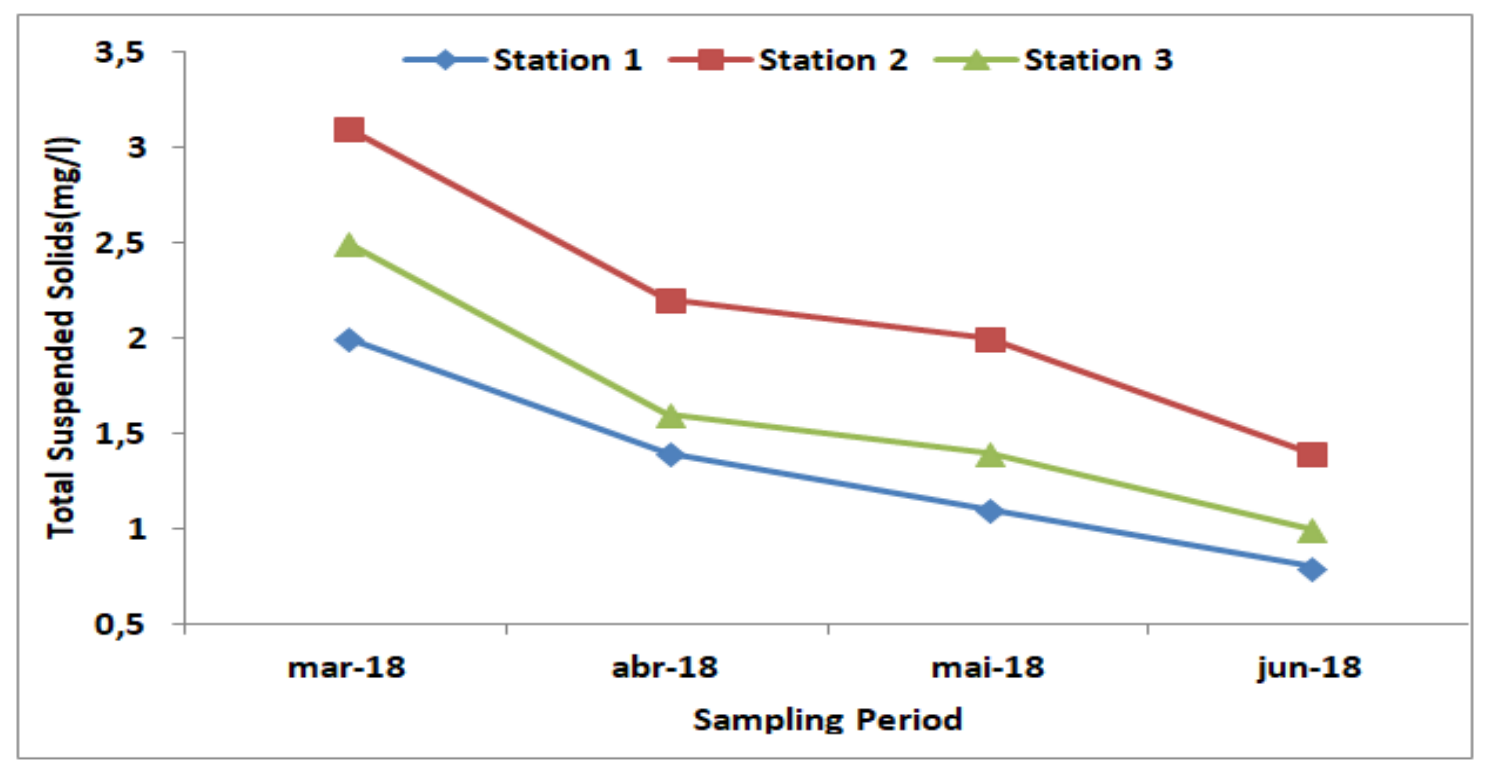

Figure 6. Temporal and spatial variations of total suspended solids recorded in the study stations.

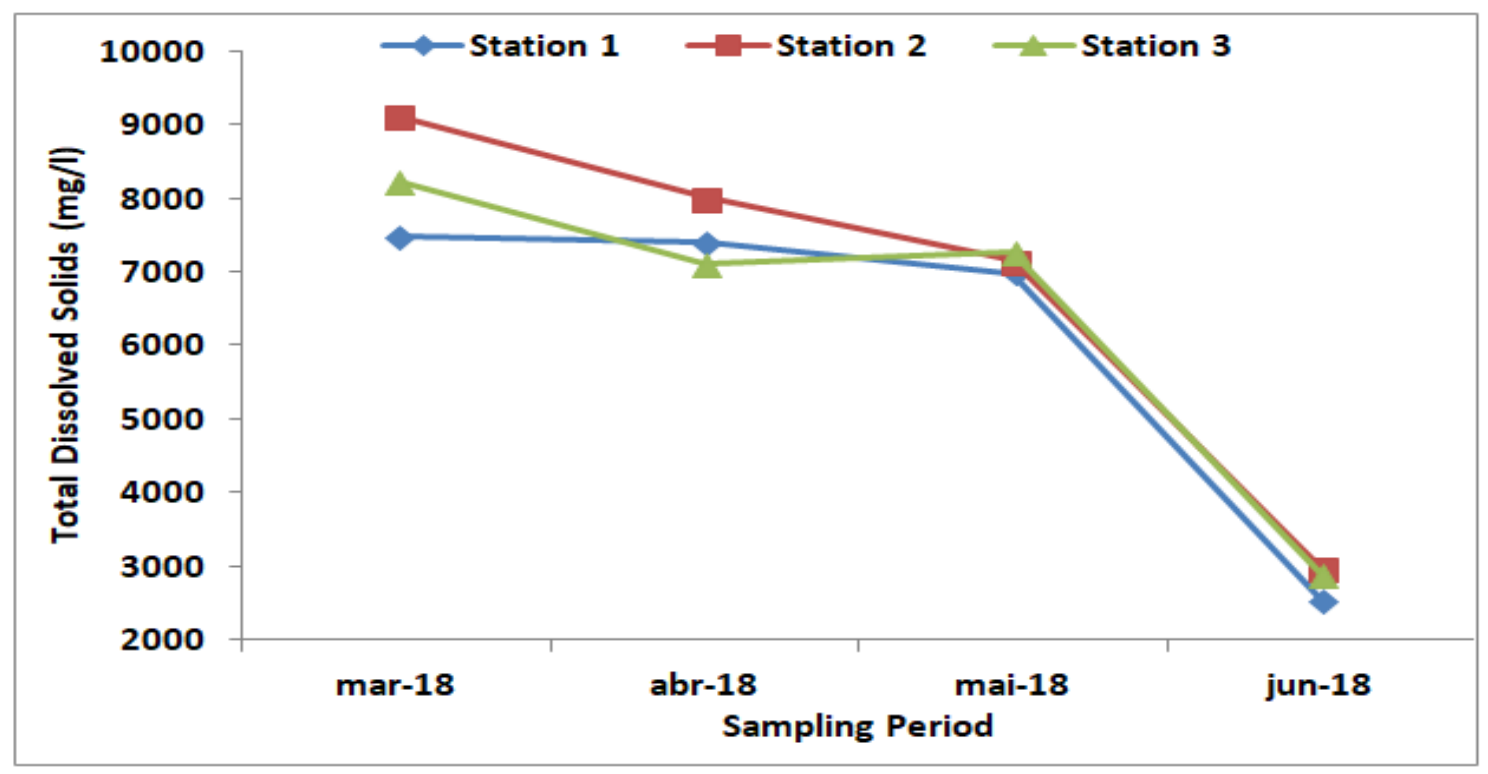

Figure 7. Temporal and spatial variations of total dissolved solids recorded in the study stations 
The recorded DO in Ibaka water body shows that the water was well oxygenated throughout the study period with a peak of $6.5 \mathrm{mg} / \mathrm{L}$ recorded in station 2. The lowest record was in station 1 (Table 1). The temporal and spatial variation is shown in Figure 8.

Biochemical oxygen demand after five days $\left(\mathrm{BOD}_{5}\right)$ was recorded.
Station 1 had the lowest $\mathrm{BOD}_{5}$ in May, 2018. Station 3 had the highest $\mathrm{BOD}_{5}$ in March, 2018 (Table 1). The values recorded are all within the acceptable maximum permitted range. The temporal and spatial variation is shown in Figure 9.

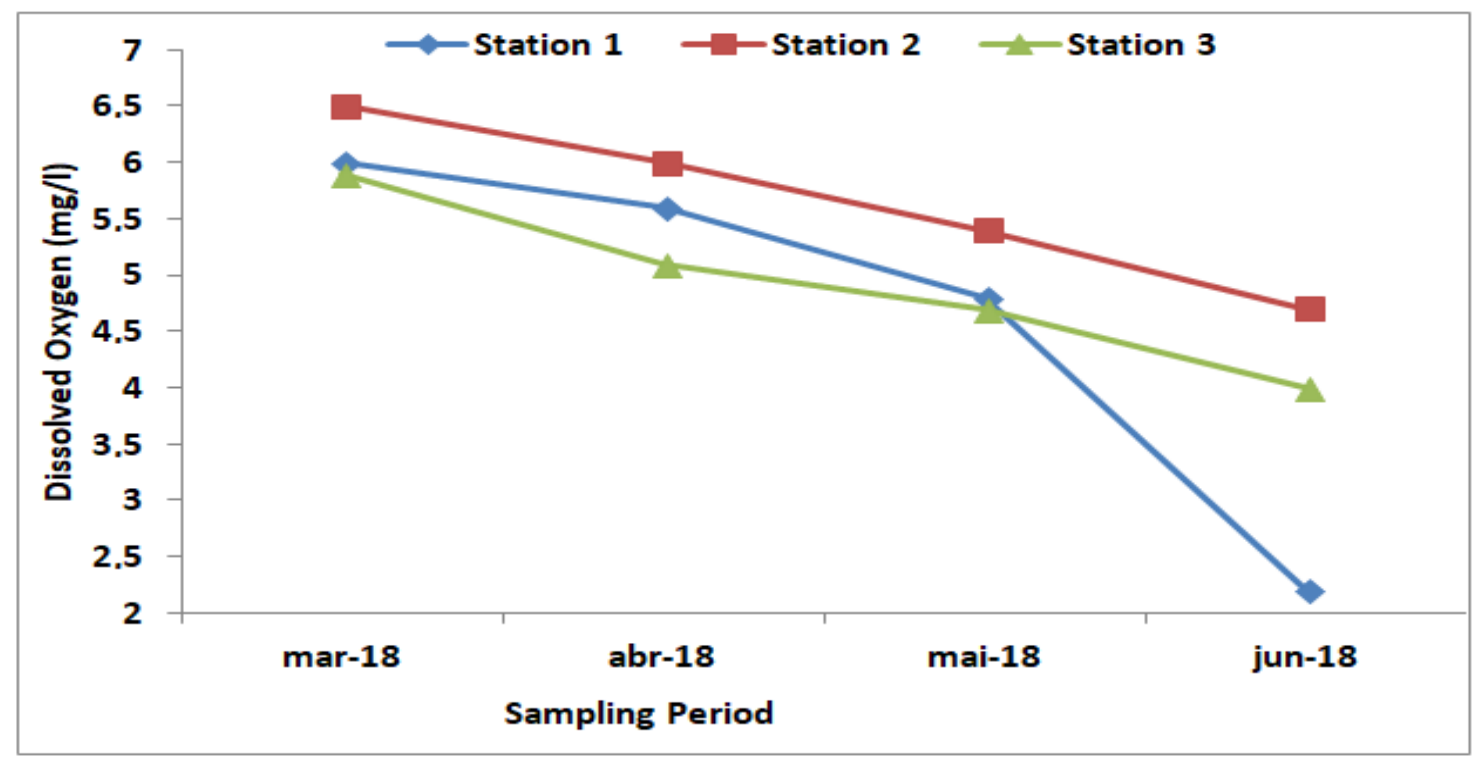

Figure 8. Temporal and spatial variations of dissolved oxygen recorded in the study stations.

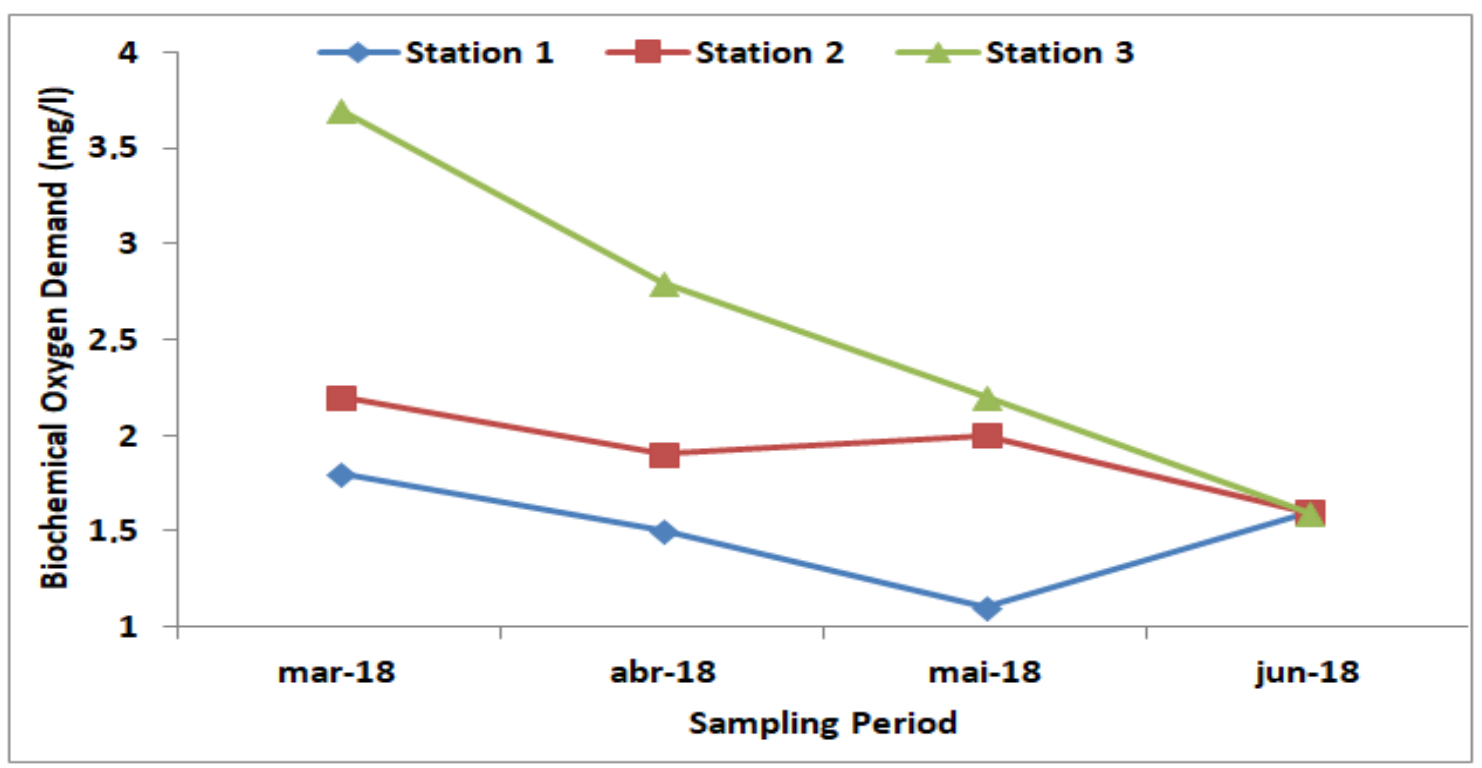

Figure 9. temporal and spatial variations of biochemical oxygen demand recorded in the study stations. 
The Chemical oxygen demand was recorded during the period of this study. The mean value was recorded and station 3 had the highest and station 1 had the lowest value (Table 1). The values are accepted within the acceptable maximum permitted range. The temporal and spatial variation is shown in Figure 10.
The temporal and spatial variations of manganese are shown in Figure 11, manganese values ranged between 0.08 and $0.33 \mathrm{mg} / \mathrm{L}$ (Table 1). The lowest value was recorded in Station 1 in June, 2018 while the highest value was recorded in Station 2 in March, 2018. The values recorded in all stations are within the acceptable maximum permitted range.

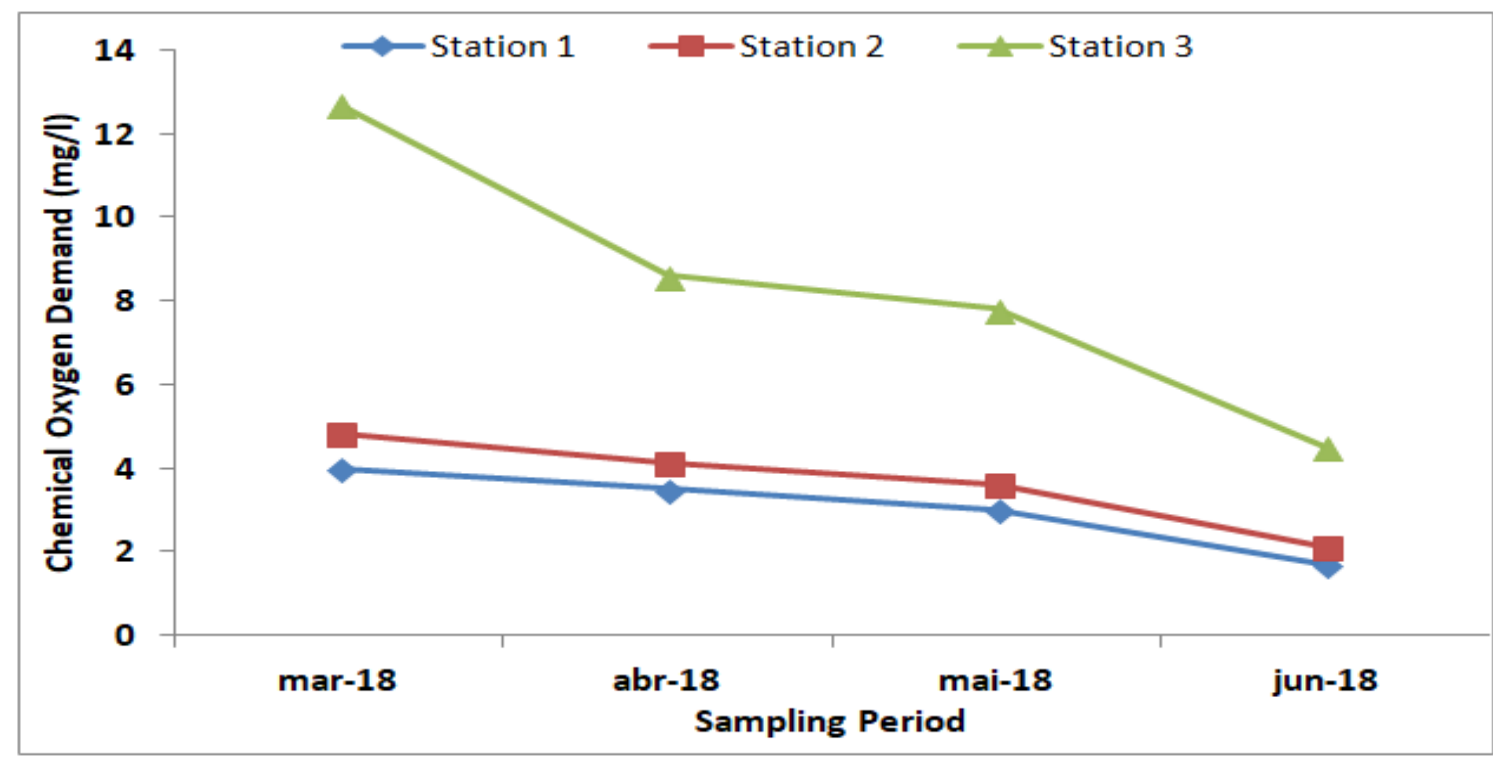

Figure 10. Temporal and spatial variations of chemical oxygen demand recorded in the study stations.

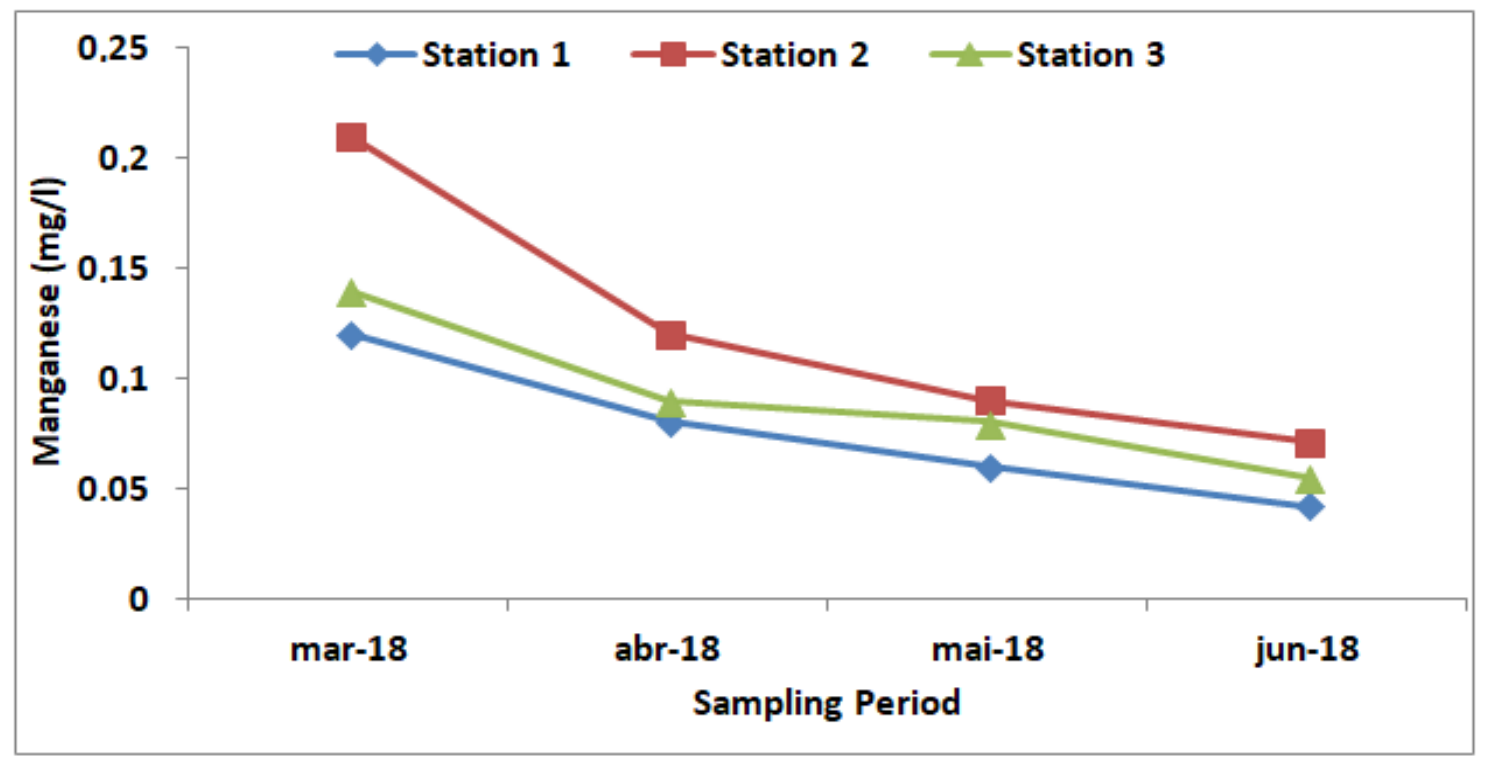

Figure 11. temporal and spatial variations of Manganese (mg/L) recorded in the study stations. 
The temporal and spatial variations of copper in Ibaka water body is shown in Figure 12. Copper values ranges between 0.02 and $0.09 \mathrm{mg} / \mathrm{L}$ (Table 1). The lowest values of copper values were recorded in station 1 in June, 2018 while the highest values were recorded in station 2 and 3 in April, 2018. All the values recorded were within the acceptable maximum permitted range.
The temporal and spatial variations of lead in Ibaka water body is shown in Figure 13. The lead values ranged between 0.001 and $0.05 \mathrm{mg} / \mathrm{L}$ (Table 1). The lowest values were recorded in station 1 in March, 2018 while the highest values were recorded in station 3 in April, 2018. All the values recorded were within the acceptable maximum permitted range.

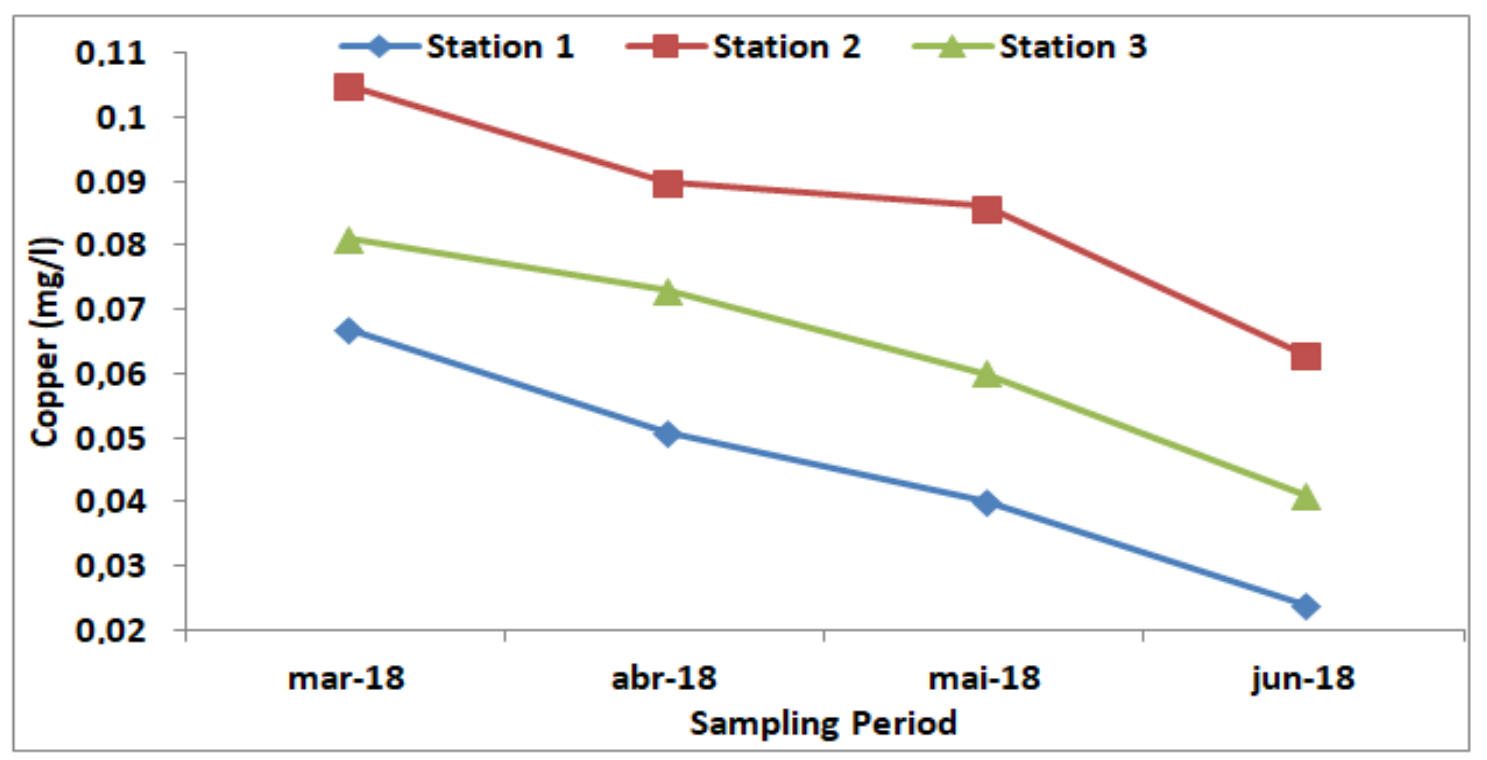

Figure 12. Temporal and spatial variations of copper $(\mathrm{Cu})$ recorded in the study stations.

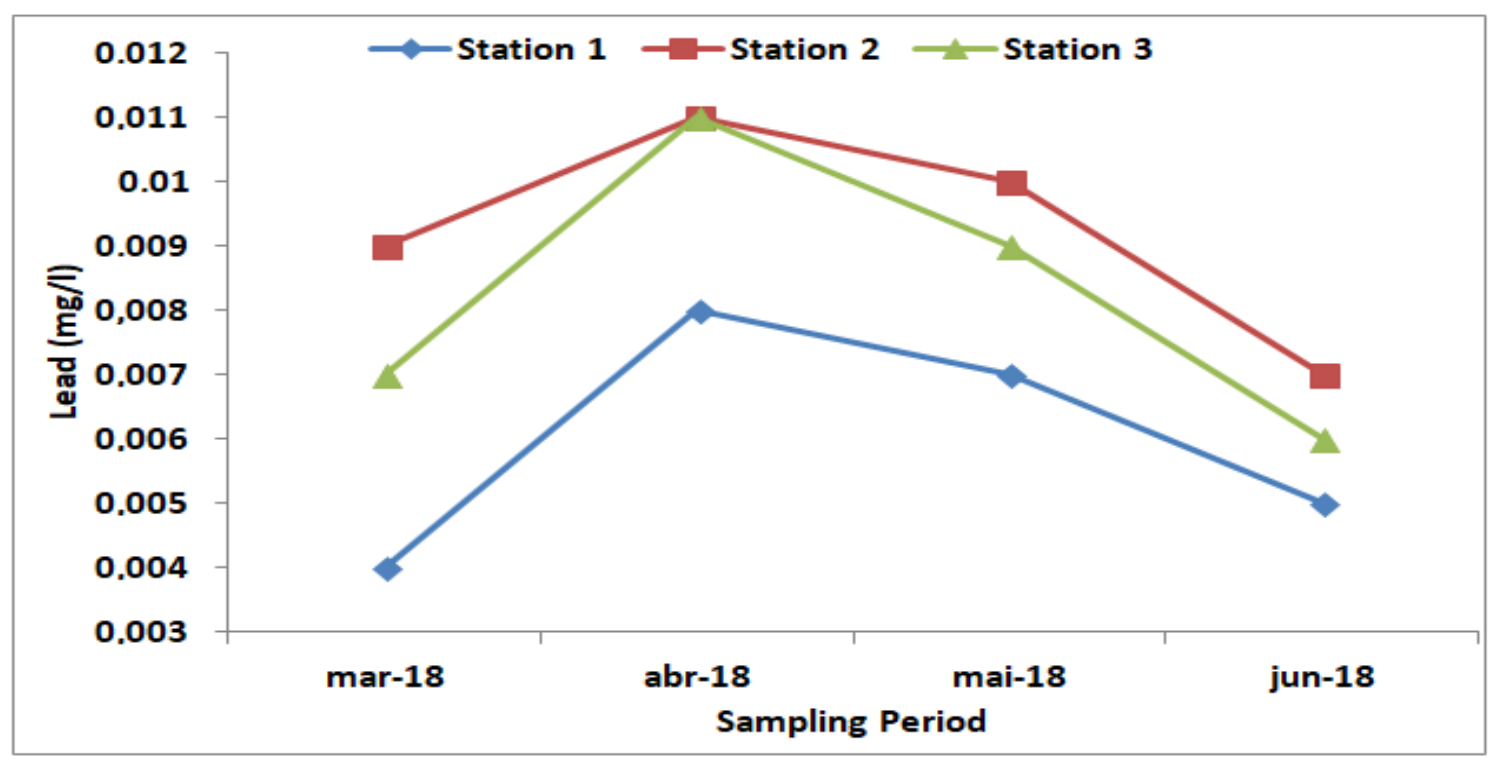

Figure 13. Temporal and spatial variations of lead $(\mathrm{mg} / \mathrm{L})$ recorded in the study stations. 
The temporal and spatial variations of Iron in the Ibaka water body is shown in Figure 14. The iron values ranged between 0.64 and 4.66 $\mathrm{mg} / \mathrm{L}$ (Table 1). The lowest value was recorded in station 1 in June, 2018 while the highest value was recorded in station 2 in March, 2018. The values recorded are not within the acceptable maximum permitted range.
The temporal and spatial variations of zinc in the Ibaka water body are shown in Figure 15. The zinc values ranged between 0.21 and $1.16 \mathrm{mg} / \mathrm{L}$ (Table 1). The lowest value was recorded in station 1 in June, 2018 while the highest value was recorded in Station 2 in March, 2018, 2018. The values recorded are not within the acceptable maximum permitted range.

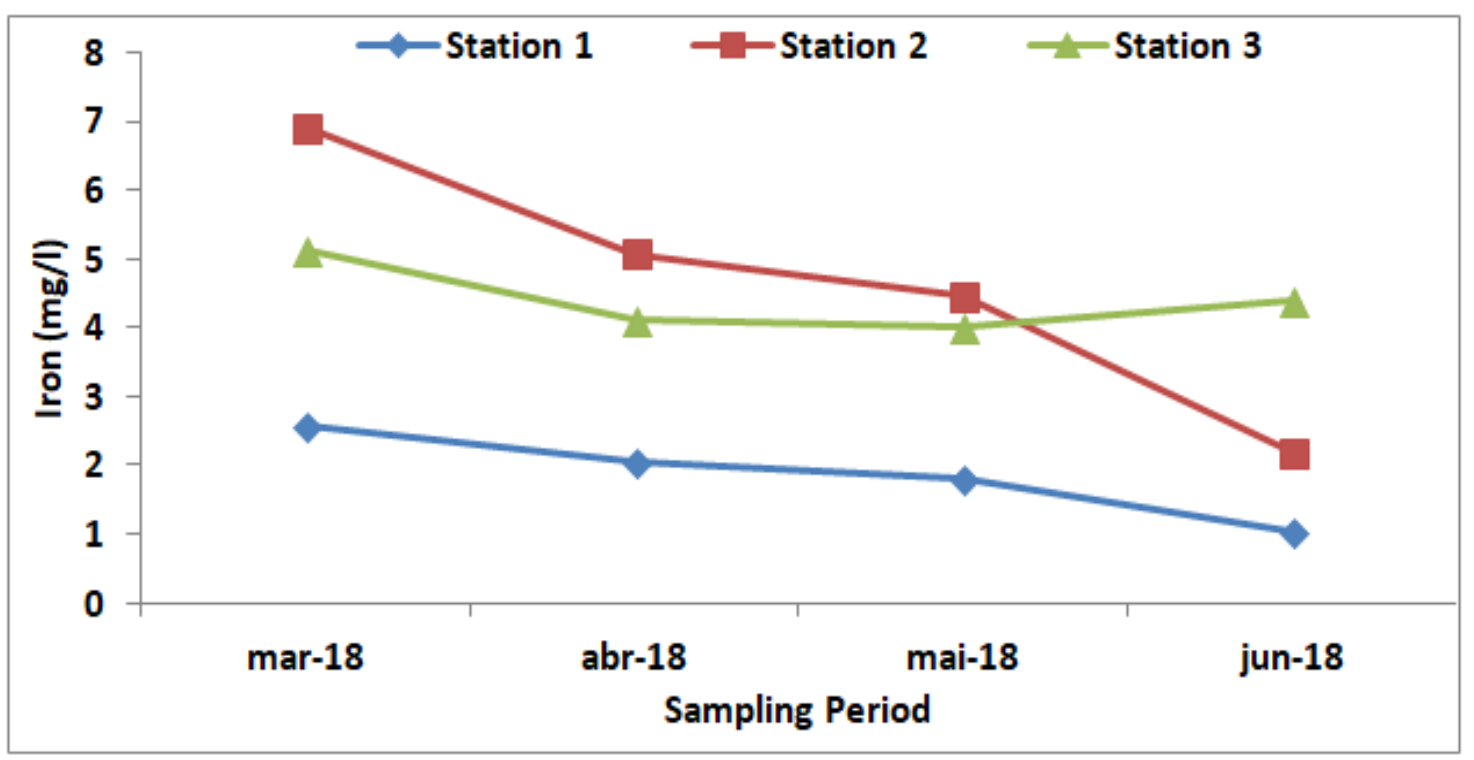

Figure 14. temporal and spatial variations of Iron recorded in the study stations

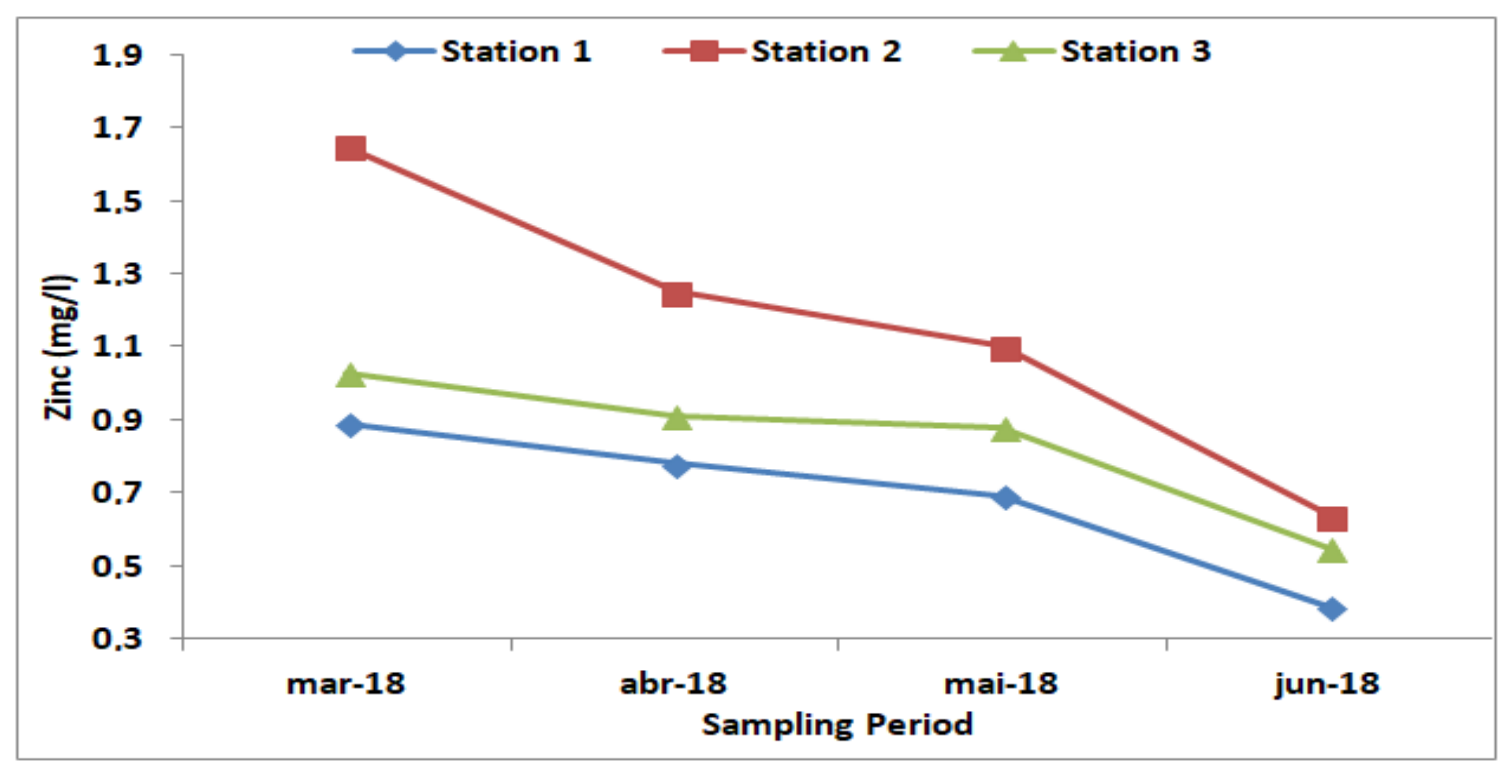

Figure 15. temporal and spatial variations of zinc recorded in the study stations. 
The temporal and spatial variations of Cadmium in the Ibaka water body are shown in Figure 16. The values ranged between 0.01 and $0.08 \mathrm{mg} / \mathrm{L}$ (Table 1). The lowest value was recorded in station 1 in June, 2018, while the highest value was recorded in station 1 in April, 2018, 2018. The values recorded are not within the acceptable maximum permitted range.
The temporal and spatial variations of chloride in the Ibaka water body are shown in Figure 17. The values ranged between 675 and $714 \mathrm{mg} / \mathrm{L}$ (Table 1). The lowest value was recorded in station 1 in June, 2018, while the highest value was recorded in station 2 in March, 2018. The values recorded are not within the acceptable maximum permitted range.

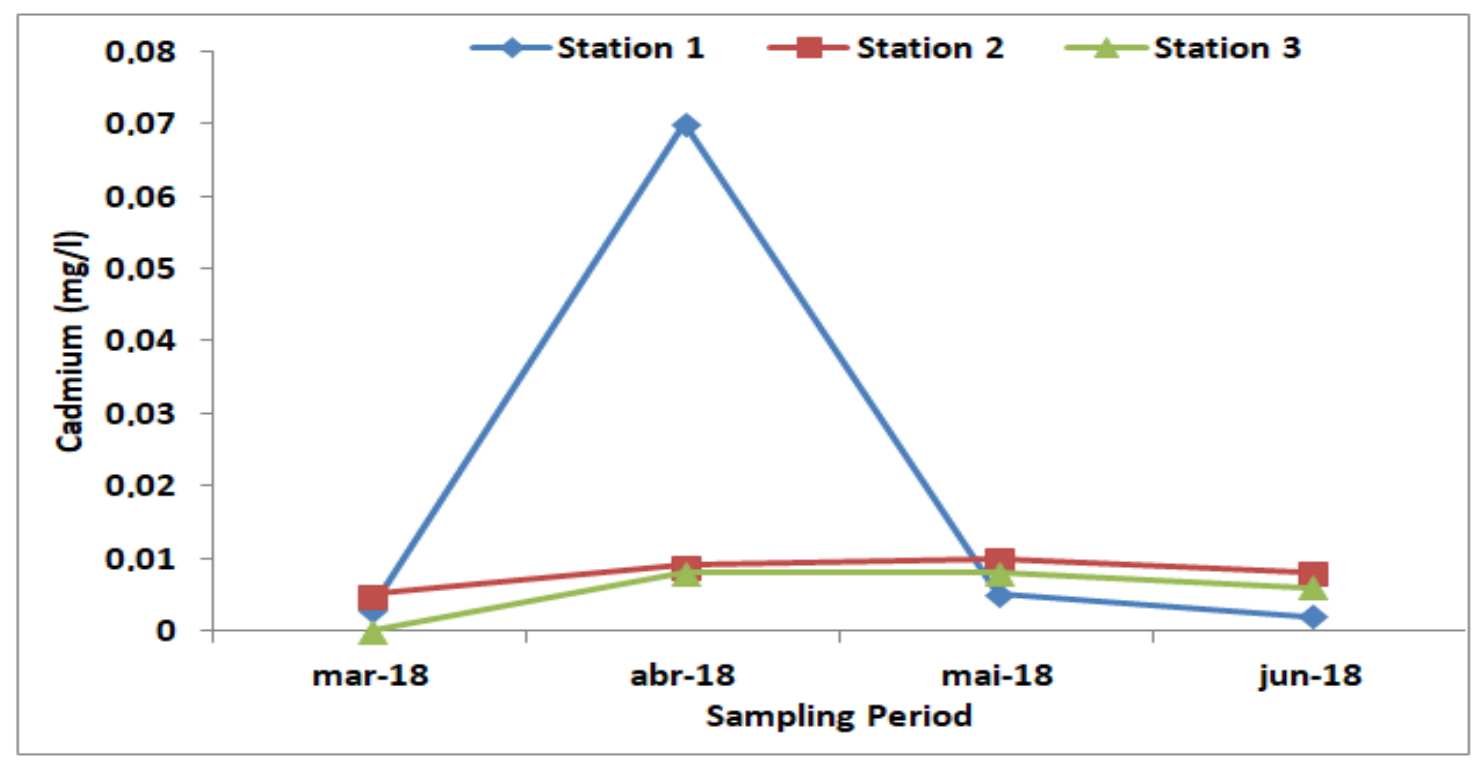

Figure 16. temporal and spatial variations of cadmium recorded in the study stations.

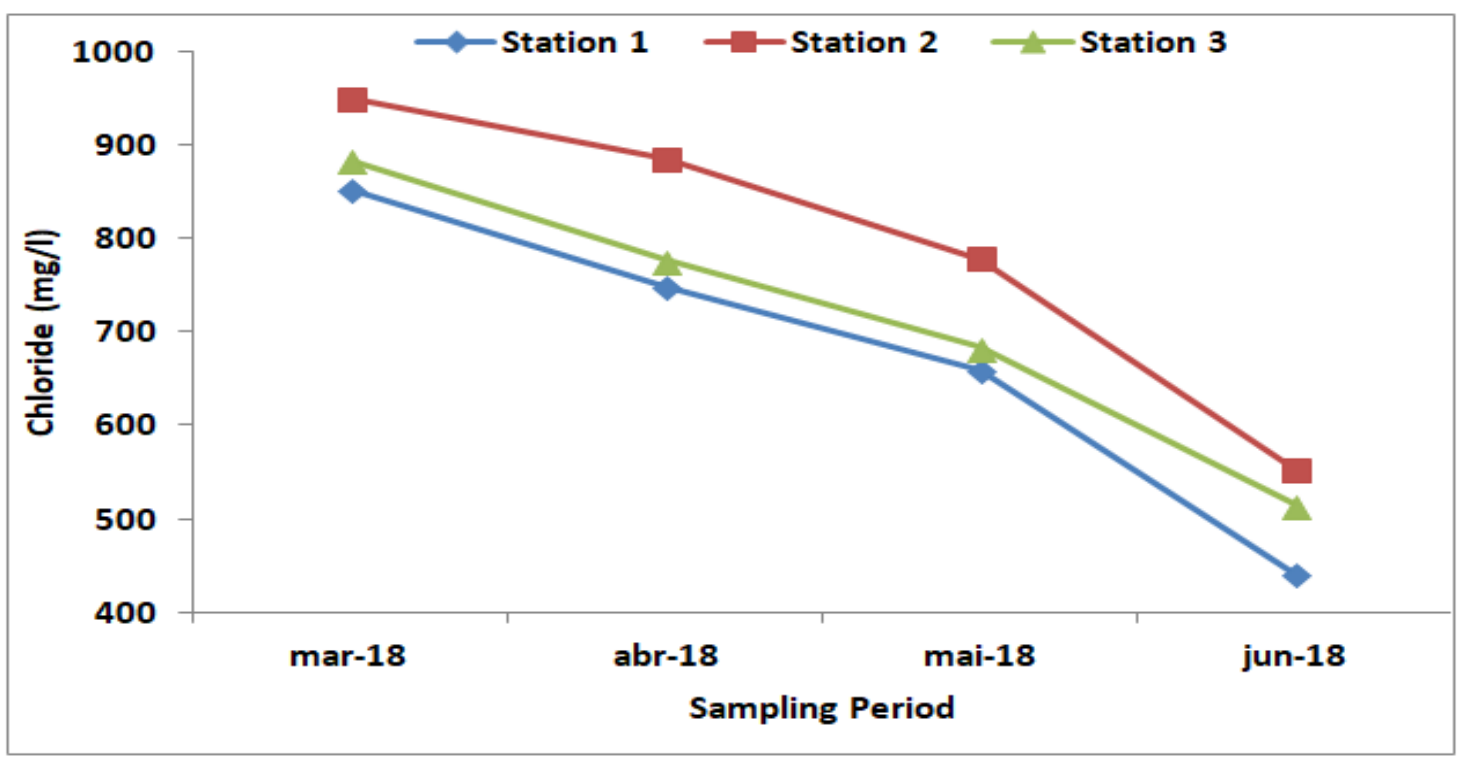

Figure 17. temporal and spatial variations of chloride recorded in the study stations. 
The temporal and spatial variations of Magnesium in the Ibaka water body are shown in Figure 18. The values ranged between 10.66 and 14.30 $\mathrm{mg} / \mathrm{L}$ (Table 1). The lowest value was recorded in station 1 in June, 2018, while the highest value was recorded in station 2 in March, 2018. The values recorded are not within the acceptable maximum permitted range.

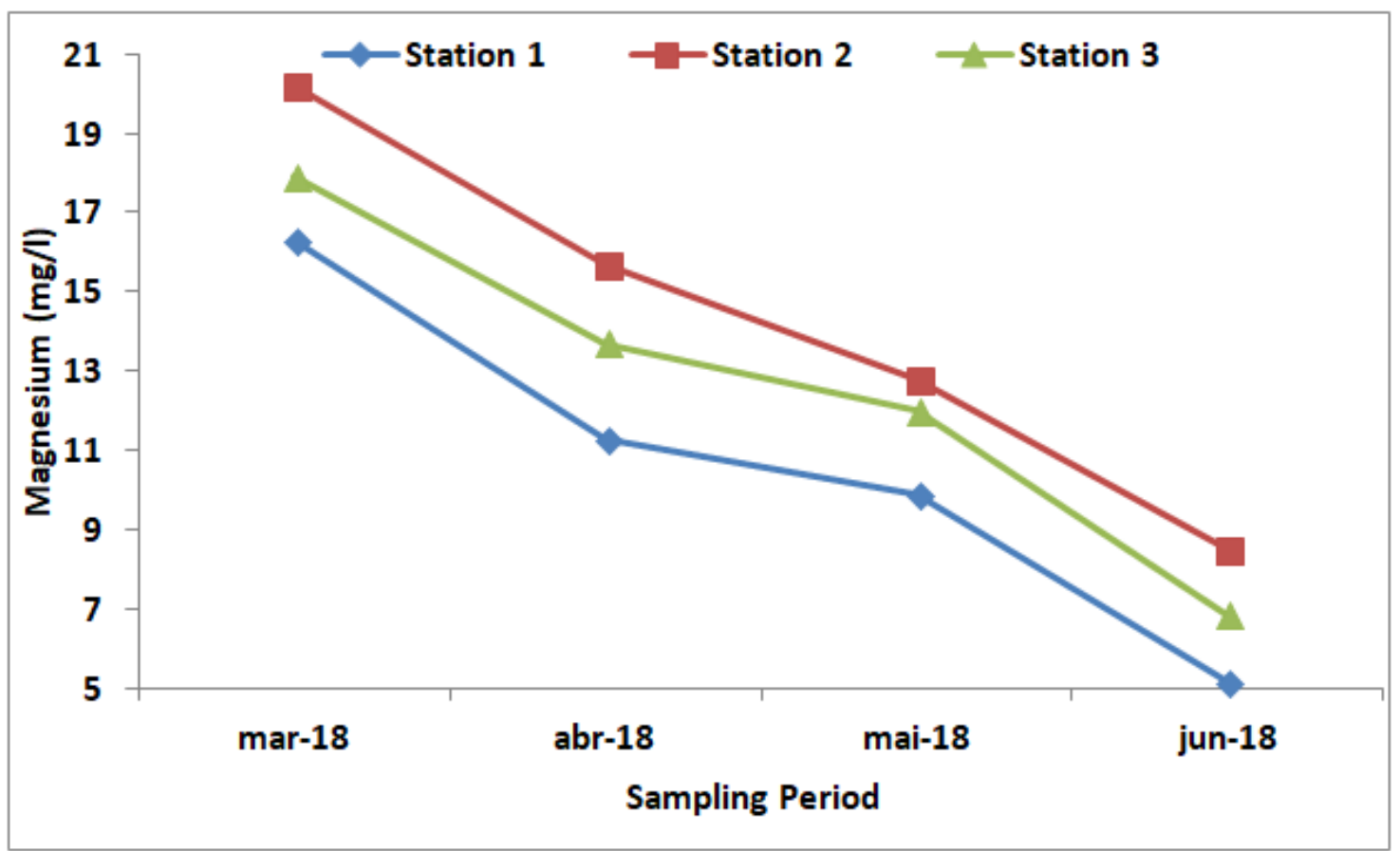

Figure 18. Temporal and spatial variations of magnesium recorded in the study stations.

\section{Conclusion}

Human disturbances, such as constant use and presence of human habitations in their vicinities, some undesirable activities of those that live along the banks of aquatic ecosystems can induce stress to aquatic organisms (Echi and Ezenwaji, 2010). Stress can permanently affect the organism by increasing the corticoid hormone production of the adrenal gland. The corticoids block the protective mechanisms of the fish phagocytosis and immune responsiveness, thereby making the fish prone to parasitic infections (Woo, 1995).

The $\mathrm{pH}$ value recorded in this study showed that the water is slightly acidic attributable to human activities, which could be as a result of the amount of dissolved carbon dioxides (Kara et al., 2004). Our drinking water $\mathrm{pH}$ level varies between 6.5 and 8.5 . The safest $\mathrm{pH}$ level of drinking water should be 7 which is the $\mathrm{pH}$ level of pure water. Based on this, the $\mathrm{pH}$ values of Ibaka water body are acceptable for drinking. Heavy metals are more soluble at low $\mathrm{pH}$ levels, metal cations are released into water body instead of being absorbed into the sediment (Radojevic and Bashkin, 1999).

The electrical conductivity value vary slightly in the three stations and are not within the range value acceptable maximum permitted rate set by WHO (2017) for drinking water, indicating a high amount of dissolved inorganic 
substances in their ionizing forms (Sankpal and Naikwade, 2012). The salinity of the water samples ranges from 5.44 to $6.19 \%$. Salinity changes in estuaries may be due to seasonal regimes of river discharges and precipitation. The salinity is high which is indicative of its brackish nature. The turbidity of the water body had the highest mean record in station 2 in March, 2018. The lowest was in station 1 in June, 2018. The values recorded shows that it is accepted within the acceptable maximum permitted range. The total suspended solids were high varying from $0.8-3.1 \mathrm{mg} / \mathrm{l}$ within the three stations. The values were not accepted within the acceptable maximum permitted range. The total dissolved solids values recorded during March, April, May, in this late dry season and early rainy months had the highest values. Dissolved oxygen in waters depends on water temperature, partial pressure of oxygen in the atmosphere and salt content in water. The dissolved oxygen ranges between 4.9 and 5.65. This shows that in all the stations, the water was well oxygenated. The biochemical oxygen demand was low in this study. The values range between 1.4 and $2.58 \mathrm{mg} / \mathrm{l}$. The values are accepted within the acceptable maximum permitted range. The chemical oxygen demand of this study values are accepted by WHO (2017). High chemical oxygen demand is as a result of both biodegradable and non-degradable introduced into the water. The recorded values of manganese did not exceed the acceptable limit. The value recorded in station 1 and station 2 is as a result of human activities. Extreme doses of manganese could lead to manganese related physiological problems (Dieter et al., 2005). Some recent studies have linked high level of manganese in drinking water and cognitive behavioural problems in children (Bouchard et al., 2007). A few studies have also reported neurological dysfunction associated with increasing levels of manganese in drinking water, whereas other studies found no neurological disorders. The nature of cellular damage caused by manganese has been attributed to its capacity to generate cytoxic levels of free radicals and manganese related neurodegeneration (Dobson et al., 2004).

Copper values were within the acceptable limits though values recorded in stations 2 and 3, were relatively high attributable to human activities. The lead values did not exceed the acceptable limits WHO (2017). The highest value recorded could be attributed to human activities while the lower values could be attributed to geologic dissolution from rocks, arising from increased rainfall. High concentration of lead can affect the central nervous, renal, hematopoietic, cardiovascular, gastrointestinal, musculoskeletal, endocrine, reproductive, neurological, developmental and immunological systems (ATSDR, 2015). The recorded value of iron exceeded acceptable limits and could be attributed to geologic dissolution from rocks influence. The trend is similar in the three stations with lower values recorded in May and June, 2018 due to dilution. In high concentration, iron may produce neurological effects (Zheng et al., 2003). Long-term iron toxicity may involve iron - mediated oxidative damage to the mitochondrial genome leading to progressive dysfunction (De Freitas and Meneghini, 2001).

All the zinc values recorded in this study were above acceptable limits. Station 2 had highest values which points to human influence. At high concentrations, cadmium affects the liver, placenta, kidney, lungs, brain and bones. Experimental data in humans and animals showed that cadmium may cause cancer in humans (Jarup et al., 2000; Nordberg et al., 2002). Chloride values recorded in this study exceeded the maximum limit. It could be attributed to human activities. High chloride concentration can give rise to detectable taste in water, but the threshold depends upon the associated cations. High 
chloride concentration in water can harm aquatic organisms by interfering with osmoregulation. High concentration of chloride causes hyperchloremia, which may include loss of body fluids from prolonged vomiting, diarrhea, sweating or high fever. Magnesium values recorded exceeded the acceptable maximum limits (WHO, 2017). Magnesium is a cofactor in more than 300 enzymes systems that regulate diverse biochemical reactions in the body, including protein synthesis, muscle and nerve function blood pressure regulation. Magnesium is also required for energy production, phosphorylation and glycolysis. It contributes to structural development of bone. Excess magnesium causes diarrhea that can be accompanied by nausea and abdominal cramping (Rude et al., 2010).

\section{Conflict of interest}

Authors declare that they have no conflict of interests.

\section{References}

Abdel Gawad, S. S. Concentrations of heavy metals in water, sediment and Mollusc Gastropod, Lanistes carinatus from Lake Manzala, Egypt. The Egyptian Journal of Aquatic Research, v. 44, no. 2, p. 77-82, 2018a. https://doi.org/10.1016/j.ejar.2018. 05.001

Abdel Gawad, S. S. Acute toxicity of some heavy metals to the fresh water snail, Theodoxus niloticus (Reeve, 1856). The Egyptian Journal of Aquatic Research,

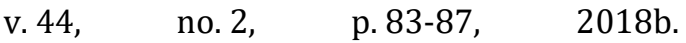
https://doi.org/10.1016/j.ejar.2018.06.004

Abdulaziz, B. A.; Mohammad, H. Role of epidemiological studies in determining environmental impact on health in Saudi Arabia. Proceeding of the Development and Environmental impact Conference, Riyadh Saudi Arabia, 1997.

Abowei, J. F. N. Salinity, dissolved oxygen, pH and surface water temperature conditions in river, Niger Delta. Advanced Journal of Food Science and Technology, v. 2, no. 1, p. 16-21, 2010.
Akpot, O. B.; Muchie, M. Remediation of heavy metals in drinking water and waste water treatment systems: Processes and application. International Journal of Physical Sciences, v. 5, no. 12, p. 1807-1818, 2010.

APHA - America public Health Association. Standard methods for the examination of water and waste water. 16. ed. Washington, D.C.: America public Health Association, 1995.

ATSDR - Agency for Toxic Substances and Disease Registry. Lead toxicity: Who is at risk of lead exposure? U.S. Department of Health and Human Services, 2015.

Awni, T. B. Heavy metals in water springs of yarmouk Basin, North Jordan and their potentiality in health risk assessment. International Journal of Physical Science, v. 5, no. 7, p. 977-103, 2010.

Bouchard, M.; Laforest, F.; Vandelac, L.; Bellinger, D.; Mergler, D. Hair manganese and hyperactive behaviours: Pilot study of school-age children exposed through tap water. Environmental Health Perspectives, v. $115, \quad$ no. $1, \quad$ p. $122-127,2007$. https://doi.org/10.1289/ehp.9504

Dara, S. S. A text book of environmental chemistry and pollution. India: S. Chand \& Co. Publishing, 1993.

De Freitas, J. M.; Meneghini, R. Iron and its sensitive balances in the cell. Mutation Research/Fundamental and Molecular Mechanisms of Mutagenesis, v. 475, no. $1 / 2$, p. 153-159, 2001. https://doi.org/ 10.1016/S0027-5107(01) 00066-5

Dieter, H. H.; Bayer, T. A.; Muthaulp, G. Environmental copper and manganese in the pathophysiology of neurologic disease (Alheimer's Disease and Manganism). CLEAN Soil Air Water, v. 33, no. 1, p. 72-78, 2005. https://doi.org/10.1002/aheh.200400556

Dirican, S.; Çilek, S.; Çiftçi, H.; Bıyıkoğlu, M.; Karaçınar, S.; Yokuș, A. Preliminary study on heavy metal concentrations of Anatolian Khramulya, Capoeta tinca (Heckel, 1843) from Çamlıgöze Dam Lake, Sivas, Turkey. Journal of Environmental Health Science and Engineering, 11:7, 2013. https://doi.org/10.1186/2052-336X-11-7

Dobson, A. W.; Erikson, K. M; Aschner, M. Manganese neurotoxicity. Annals of the New York Academy of Sciences, v. 1012, no. 1, p. 115-128, 2004. https://doi.org/10.1196/ annals.1306.009 
Domingo, J. L. Metal-induced developmental toxicity in mammals: A review. Journal of Toxicology and Environmental Health, v. 42, no. 2, p. 123-141, 1994. https://doi.org/10.1080/152873994095318 68

Echi, P. C.; Ezenwaji, H. M. G. The parasite fauna of characids' (Osteichthyes: Characidae) Anambra River, Nigeria. African Journal of Ecology, v. 48, p. 1-4, 2010. https://doi.org/10.1111/j.1365-2028.2009. 01030.x

Ghorade, I. B.; Jadhavar, V. R.; Patil, S. S. Assessment of heavy metal content in Godaviri River Water. Impart: International Journal of Research in Applied, Natural and Social Sciences, v. 2, no. 6, p. 23-26, 2014. Available from: <http://www.impact journals.us/download/archives/2-141401469786-4. Applied-Assessment of heavy metal content in godavari-Ghorade I. B.pdf>. Accessed on: Mar. 17, 2018.

Goorzadi, M.; Vahabzabeh, G.; Ghanbarpour, M. R.; Karbassi, A. R. Assessment of heavy metal pollution in Tilehbon River sediments, Iran. Journal of Applied Science, v. 9, no. 6, p. 1190-1193, 2009. https://doi.org/ 10.3923/jas.2009.1190.1193

Iwuoha, G. N.; Onojake, M. C. Bioaccumulation of heavy metals in crustaceans from Oron River Channel, Osung Area Oron-City, AkwaIbom, Nigeria. Journal of Chemical Society of Nigeria, v. 41, n. 1, p. 33-35, 2016. Available from: <http://journals.chem society.org.ng/index.php/jcsn/article/view/ 43/130>. Accessed on: Mar. 17, 2018.

Jaishankar, M.; Tseten, T.; Anbalagan, N.; Mathew, B. B.; Beeregowda, K. N. Toxicity, mechanism and health effects of some heavy metals. Interdisciplinary Toxicology, v. 7, no. 2 , p. $60-72$, 2014. https://doi.org/ 10.2478/intox-2014-0009

Jarup, L.; Hellstorm, L.; Alfven, T.; Carlsson, M. D.; Grubb, A.; Person, B.; Petersson, C.; Spang, G.; Schutz, A.; Elinder, C. G. Low level exposure-cadmium and early kidney damage: The OSCAR study. Occupational and Environmental Medicine, v. 57, p. 668-672, 2000. https://doi.org/10.1136/oem.57. 10.668

Kara, Y.; Kara, I.; Basaran, D. Investigation of some physical and chemical parameters of water in the Lake Isyki in Denisti, Turkey. International Journal of Agriculture and Biology, v. 6, no. 2, p. 275-277, 2004.
Lane, T. W.; Morel, F. M. A biological function for cadmium in marine diatoms. PNAS, v. 97, no. 9, p. 4627-4631, 2000. https://doi.org/ 10.1073/pnas.090091397

LENNTECH. Heavy metals. 2012. Available from: <https://www.lenntech.com/ processes/heavy/heavy-metals/heavymetals.htm>. Accessed on: Mar. 17, 2018.

Mallampti, S. R.; Bhavesh, M.; Sunil, D.; Manish, J.; Leena, K. Venkatrama, K. S. S.; Shaik, B.; Prashant, B. Bio-accumulation of heavy metals in some commercial fishes and crabs Gulf of Cambey, India. Current Science Journal, v. 92, no. 11, p. 1489-1491, 2007.

Namaghi, H. H.; Karami, G. H.; Saadat, S. A. Study on chemical properties of groundwater and soil in ophiolitic rocks in Firuzabad, East of Shahrood, Iran: With emphasis to heavy metal contamination. Environmental Monitoring Assessment, v. 174 , no. $1 / 4$, p. 573-583, 2011. https://doi.org/10.1007/ s10661-010-1479-3

NORD - National Organization for Rare Disorders. Heavy metal poisoning. Available from: <http://www.rarediseases.org/rarediseases/heavy-metal-poisoning/>. Accessed on: Feb. 4, 2018.

Nordberg, G.; Jin, T.; Benard, A.; Fierens, S.; Buchet, J. P.; Ye, T.; Kong, Q.; Wang, H. Low bone density and renal dysfunction following environmental cadmium exposure in China. AMBI0: A Journal of the Human Environment, v. 31, no. 6, p. 478-481, 2002. https://doi.org/10.1579/0044-744731.6.478

Nsikak, U. B.; Joseph, P. E.; Akpan, B. W.; David, E. B. Mercury accumulation in fishes from tropical aquatic ecosystems in the Niger Delta. Nigerian Current Science, v. 92, no. 6, p. 781-785, 2007.

Otitoju, O.; Otitoju, G. T. O. Heavy metal concentrations in water, sediment and periwinkle (Tympanotonus fuscastus) samples harvested from the Niger Delta Region of Nigeria. African Journal of Environmental Science and Technology, v. 7, no. 5, p. 245-248, 2013.

Radojevic, M.; Bashkin, V. N. Practical environmental analysis. Cambridge, UK: Royal Society of Chemistry, 2004.

Rude, R. K.; Coates, P. M.; Betz, J. M.; Blackman, M. R.; Cragg, G. M.; Levine, M.; Moss, J.; White, J. D. Magnesium. In: Coates, P. M.; Betz, J. M.; Blackman, M. R.; Cragg, G. M.; Levine, M.; Moss, J.; White, J. D. (Eds.). 
Encyclopedia of dietary supplements. Boca Raton: Informa Healthcare, 2010, p. 527-537.

Sala, O. E.; Chapin III, F. S.; Armesto, J. J.; Berlow, E.; Bloomfield, J.; Dirzo, R.; HuberSanwald, E.; Huenneke, L. F.; Jackson, R. B.; Kinzig, A.; Leemans, R.; Lodge, D. M.; Mooney, H. A.; Oesterheld, M.; Poff, N. L.; Sykes, M. T.; Walker, B. H.; Walker, M.; Wall, D. H. Global biodiversity scenarios for the Year 2100. Science, v. 287, no. 5459, p. 1770-1774, 2000. https://doi.org/10.1126/science.287. 5459.1770

Sankpal, S.; Naikwade, P. V. Physico-chemical analysis of effluent discharge of fish processing industries in Ratnagiri India. Bioscience Discovery, v. 3, no. 1, p. 107-111, 2012.

Sharma, B.; Tyagi, S. Simplification of metal ion analysis in water samples by atomic absorption spectroscopy for laboratory students. Journal of Laboratory Chemical Education, v. 1, no. 3, p. 54-58, 2013. https://doi.org/10.5923/j.jlce.20130103.04 WHO - World Health Organization. Guideline for drinking water quality. 4. ed. Geneva, Switzerland: WHO, 2017. Available from: <https://www.who.int/water_sanitation_hea lth/publications/drinking-water-qualityguidelines-4-including-1st-addendum/en/> . Accessed on: Feb. 4, 2018.
Woo, P. T. K. Fish diseases and disorders. Wallingford: CAB International, 1995. (v. 1, Protozoan and metazoan infections).

Zheng, N.; Liu, J.; Wang, Q.; Liang, Z. Health Risk assessment of heavy metals exposure to street dust in the zinc smelting district, Northeast China. Science of the Total Environment, v. 408, no. 4, p.726-733, 2010. https://doi.org/10.1016/j.scitotenv. 2009.10.075

Zheng, W.; Aschner, M.; Ghers-Egea, J. F. Brain barrier systems: A new frontier in metal neurological research. Toxicology and Applied Pharmacology, v. 192, no. 1, p. 111, 2003. 